\title{
Entrepreneurial Growth Ambitions: The Case of Finnish Technology Startups
}

\author{
Arto Wallin, Kaisa Still, and Katja Henttonen
}

\author{
"Growing up is losing some illusions," \\ in order to acquire others. \\ Virginia Woolf (1882-1941) \\ Author, publisher, and critic
}

\begin{abstract}
Technology startups are expected to be a major driving force of economic growth in Europe. The search for new high-growth startups has been particularly topical in Finland, the country that is known for its high-tech products - and the fall of Nokia's mobile phone business. Although a record number of startups has been established in recent years, the previously identified challenge is that only a small percentage of entrepreneurial businesses are responsible for the lion's share of economic benefits typically associated with entrepreneurial activity. Hence, we need better understanding of what level of growth technology entrepreneurs aim to create and why there may be differences in growth ambitions among them. In this study, we undertook interpretivist case study research in pursuit of rich, empirically grounded understanding of entrepreneurial growth ambitions in the context of Finnish technology startups. We interviewed entrepreneurs at a Finnish startup event and supplemented this information with data available publicly on the Internet related to the growth ambitions of startups. Our study sought to increase understanding of the different aspects of entrepreneurial growth ambitions, and to explore the relationship between context and growth. Based on the findings, we suggest that growth ambitions should be seen as a complex, socially constructed concept. The growth ambitions of entrepreneurs in our study were influenced, at least in part, by their startups' institutional and market contexts, the scalability of their business models, their personal characteristics and experience, and their perceptions of the barriers and constraints of the field. We conclude that startups have very different growth pathways: although the growth of one startup may depend on the talent of a few software developers, the growth of another startup may be based on its success in building international sales networks. As a result, to get most out of the support provided for a startup ecosystem, support activities should be tailored to different types of high-growth startups.
\end{abstract}

\section{Introduction}

When Nokia's dominance of the mobile phone market came crashing down, it was a disaster for the Finnish economy and left a huge gap to fill, especially for the employment of engineers (Lane, 2016). Since then, Finnish decision makers have been expecting new ventures - particularly technology startups - to fill the gap and lift the Finnish economy out from the recession. But this idea has a hidden assumption that might not hold: do all startups have growth ambitions? Do they want to be global players like Nokia? And most importantly, do they build their growth by employing thousands of employees as Nokia did?

Finland is a contradictory context for technologybased growth entrepreneurship. Although the country is known for its high-tech contributions and has frequently ranked in the top category in innovativeness and competitiveness (e.g., Schwab \& Sala-i-Martin, 2014), the Finnish society has traditionally been rather discouraging to high personal ambitions, as seen for ex- 


\section{Entrepreneurial Growth Ambitions: The Case of Finnish Technology Startups}

Arto Wallin, Kaisa Still, and Katja Henttonen

ample in the education system, which has been designed toward equality not excellence. Furthermore, the high-tech sector, dominated by Nokia, was not known for having an entrepreneurial mind-set. However, the fall of Nokia created the gap and incentives for entrepreneurship, which has made a major contribution toward the currently flourishing Finnish startup ecosystem. As an example, Nokia's Bridge funding program provided startup funding and support for past Nokia employees to encourage them to establish hundreds of startup companies (Bosworth, 2014). In addition, Finland is widely recognized as a leader in highgrowth entrepreneurship policy (Autio \& Rannikko, 2016; Mason \& Brown, 2013) where many kinds of public funding and support services are offered for startups with the hope of benefits for the local, regional, and national economies.

Although there is extensive research related to entrepreneurial growth, we have identified some existing gaps between research and practice. First, much of the literature on entrepreneurial growth emphasizes the characteristics of the individual. Although some recent empirical studies highlight the importance of the context, for example Sipola (2015) found that entrepreneurial growth ambitions differ between countries, most of the studies are not fully taking into account how complex institutional forces and market environments may influence growth. In order to fully capture the importance of context for growth, we need to have very rich and diverse empirical coverage of this topic. Second, our literature review points out that the concept of growth is still largely translated into employment. However, in practice, we see the emergence of new kinds of startups that grow multibillion-dollar revenues with very few employees. The Finnish game company SuperCell (supercell.com) is a great example: established in 2010, five years later it achieved an annual revenue of $\$ 2.3$ billion with only 176 employees (Takahashi, 2016). It is clear that we need to rethink the concept of growth for today's technology startups.

The objective of this article is to provide rich, empirically grounded analysis of entrepreneurial growth ambitions in the context of Finnish technology startups. Our study aims to increase understanding of the different aspects of entrepreneurial growth ambitions and to explore the relationship between context and growth. In short, our research question is the following: what kind of growth do technology entrepreneurs aim to create and why there are differences in growth ambition levels? We believe that, with better understanding of the growth ambitions of technology entrepreneurs, we may better help them achieve such growth, which is especially important now that digitalization and globalization have set the potential for unprecedented growth in technology-based startups.

\section{Related Research}

In this article, we do not aim to provide a comprehensive review of extant literature of entrepreneurship, which is largely founded on the 1934 definition by Schumpeter of an entrepreneur as an individual whose function is to carry out new combinations of means of production. Entrepreneurship has been explored by multiple terms - for example, there is prominent research on technology startups and technology-based innovations in various research streams. Given that we want to explore the growth ambitions of entrepreneurs, we need to understand the phenomenon and the role of growth in entrepreneurship. In addition, we see growth ambitions going beyond the often-mentioned motivation of entrepreneurship as "the creation of wealth and commercialization of an idea" (Carbonell et al., 2009). The primary focus of the academic literature on entrepreneurship has been on the individual (Autio et al., 2014). However, going beyond the individual has been increasingly highlighted. For example, technology entrepreneurship is seen to eliminate the focus on individual entrepreneurs (Bailetti, 2012a) with increased emphasis on stakeholders and multiple actors (Autio et al., 2014), as well as with venture capitalists and customers being part of the ecosystem (Sipola, 2015). Similarly, within the stream of technology startups, there is much interest on how individual-level factors correlate with entrepreneurship and commercialization behaviours. For example, Nelson (2014) points out that the role of context in shaping entrepreneurial behaviour is less clear and suggests that the relationship between context and entrepreneurship should be studied in greater detail.

\section{Entrepreneurship, innovation, and growth}

As can be seen in Table 1, there are multiple approaches to entrepreneurship that all highlight different elements. We categorized these approaches based on their focus as it is explained in the definitions. Subsequently, we identified two main categories, which we acknowledge are inherently related.

First, we recognize that entrepreneurship is seen to be linked to technology and innovation with concepts such as technology entrepreneurship (Bailetti, 2012a). 


\section{Entrepreneurial Growth Ambitions: The Case of Finnish Technology Startups} Arto Wallin, Kaisa Still, and Katja Henttonen

Table 1. Emphasis on entrepreneurship concepts in the literature

\begin{tabular}{lll}
\hline Area & Concept & Perspective \\
\hline $\begin{array}{l}\text { Innovation, } \\
\text { invention, and } \\
\text { technology }\end{array}$ & $\begin{array}{l}\text { Technical entrepreneurship } \\
\text { (Carbone, 2009) }\end{array}$ & $\begin{array}{l}\text { Technical entrepreneurship is often associated with innovation, } \\
\text { research, and invention. }\end{array}$ \\
\cline { 2 - 3 } & $\begin{array}{l}\text { Technology entrepreneurship } \\
\text { (Bailetti, 2012a) }\end{array}$ & $\begin{array}{l}\text { An investment in a project that assembles and deploys specialized } \\
\text { individuals and heterogeneous assets that are intricately related to } \\
\text { advances in scientific and technological knowledge for the purpose of } \\
\text { creating and capturing value for a firm }\end{array}$ \\
\hline
\end{tabular}

\section{Growth and disruption}

\begin{abstract}
High-growth entrepreneur
(Minniti et al., 2005)
\end{abstract}

High-expectation entrepreneurial activity is defined as early-stage businesses that expect to employ at least 20 employees within five years' time.

\begin{tabular}{ll}
\hline $\begin{array}{l}\text { Born global } \\
\text { (Knight, 2015) }\end{array}$ & $\begin{array}{l}\text { Highly international small and medium-sized enterprises that } \\
\text { undertake international business at or near their founding }\end{array}$ \\
\hline $\begin{array}{l}\text { Entrepreneurial innovation } \\
\text { (Autio et al., 2014) }\end{array}$ & $\begin{array}{l}\text { Entrepreneurial innovation involves the disruption of existing } \\
\text { industries and creation of new ones through multi-level processes and } \\
\text { stakeholders, multiple actors, and multiple contexts. }\end{array}$ \\
\hline $\begin{array}{l}\text { Startup ecosystem } \\
\text { (Sipola et al., 2016) }\end{array}$ & $\begin{array}{l}\text { A startup ecosystem is a platform for high-growth entrepreneurship } \\
\text { with constituencies that influence the emergence and non-emergence } \\
\text { of high-growth firms. }\end{array}$ \\
\hline
\end{tabular}

Ambitious entrepreneur

(Hermans et al., 2015)
Someone who engages in the entrepreneurial process with the aim to create as much value as possible
Successful technology-based ventures are seen to heavily depend on the outcomes of actions by entrepreneurs and their ability to not only combine resources but also tolerate a higher degree of uncertainty (Giones et al., 2013). Much of the research has been concentrating on what type of resource configurations or combinations would explain the success or failure of the technology innovations of so many promising ventures (Giones \& Miralles, 2015). Much of this research is dominated by studies of innovation in established companies; for example, Freeman and Engel (2007) explain that the corporate model of innovation differs significantly from the entrepreneurial model of innovation, which has been proven as "a robust vehicle for breakthrough innovations" and therefore deserves better attention.

Second, multiple concepts related to entrepreneurship emphasize growth. Concepts such as the high-growth entrepreneur and the ambitious entrepreneur are based on the understanding that an entrepreneurial venture has the principal goal of creating jobs or value. The born-global research stream (Bailetti, 2012b; Knight \& Cavusgil, 1996; Tanev, 2012) provides more co- herent concept defining a born-global firm as a highly international small and medium-sized enterprise that undertakes international business at or near its founding (Knight, 2015).

\section{Growth ambitions}

The impact of goals and ambitions on entrepreneurial innovation activities has also been studied in innovation research and other related streams, but the research is scattered. One of the challenges related to this research is that the issue is discussed with many names. For example, growth ambitions (Gundry \& Welsch, 2001), growth willingness (Davidsson, 1989), intended growth and growth intentions (Cassar, 2006), growth preferences (Cassar, 2007), attitude toward growth (Cliff, 1998; Wiklund, Davidsson, \& Delmar, 2003), and growth aspirations (Kolvereid, 1992; Tominc \& Rebernik, 2007) are all terms that are used in studies that generally aim to understand why and how entrepreneurs seek (or do not seek) high growth. Although these concepts have varying meanings for growth, many of those regard growth as increase in employment. 


\title{
Entrepreneurial Growth Ambitions: The Case of Finnish Technology Startups
}

\author{
Arto Wallin, Kaisa Still, and Katja Henttonen
}

A growing body of knowledge emphasizes that some entrepreneurs have higher ambitions than others, and that these entrepreneurial ambitions are an important antecedent of actual firm outcomes (Hermans et al., 2015). Again, as in the entrepreneurship literature in general, one of the explaining factors for growth ambitions of entrepreneurs is related to the types of people that become startup entrepreneurs in the first place. Lee and Venkataraman (2006) theorize about this process and claim that each individual has a combination of economic, social, and psychological benefits, collectively called the aspiration vector, that defines the set of entrepreneurial opportunities open to that individual. In a combination of available non-entrepreneurial options, the aspiration vector explains why individuals with certain type of human, intellectual, and social capital become entrepreneurs. Verheul and van Mil (2011)support this theoretical frame and link it to growth ambitions. In their study, they found out that Dutch early-stage entrepreneurs who are exploiting a perceived business opportunity ("opportunity entrepreneurs"), as opposed to those who became entrepreneurs due to lack of alternative employment options ("necessity entrepreneurs"), are more likely to have high growth ambitions. The context of entrepreneurship has also been addressed by Sipola and colleagues (2016), who compared high-growth-ambition startups in three different countries and found clear differences in internationalization activities, which were related to attributes such as ambition levels, a sense of urgency, and the accountability of the entrepreneur. These attributes were strongly linked to the cultural-cognitive and regulative level of the society.

A recent attempt to bring structure to addressing growth ambitions is the framework of ambitious entrepreneurship, with its three major concepts: i) growth aspiration (what the entrepreneur ideally wants to achieve), ii) growth intention (what the entrepreneur intends to achieve, combined with the effort they intend to make), and iii) growth expectation (what the entrepreneur wants to achieve, combined with the opportunities and constraints they perceive) (Hermans et al., 2015). It should be noted that all sample questions used to obtain answers for each of these concepts included the number of jobs as a measure of growth. For example, growth intention is typically addressed with the following question: within 5 years, how many employees do you intend to employ in this firm? Consequently, methods for measuring growth ambition need to be updated if we want to capture all aspects of the growth of modern technology startups.

\section{Methodology}

This study utilizes case studies as a research strategy because the aim is to analyze the contemporary phenomenon of entrepreneurial growth ambitions within a real-life context (Chetty, 1996; Ghauri, 2004). We decided to conduct a multiple comparative case study (Mills et al., 2006) in order to better understand the contrasts, similarities, and patterns in entrepreneurial innovation, especially from the viewpoint of growth ambitions. The context of the research is growth-seeking technology startups established in Finland. The selected approach to case study research could also be described as interpretivist because the goal is to accumulate understanding on the topic rather than to make measurements or predictions (Andrade, 2009; Walsham, 1995).

For data collection, the researchers went to the major technology startup event in Finland, where growthseeking Finnish startups are expected be present to investors, although it is also one of the biggest startup events in whole Europe. The event was called Slush (slush.org) and it was held in Helsinki from November $12-13,2015$. The primary data was collected with short (10-20 minute) semi-structured interviews conducted by three researchers during the two-day event. In the interview, the ambition level was approached with the question "where will your company be in 5 years".

In total, 27 interviews were conducted from which 21 Finnish companies were selected for further data collection and analysis. Relevant contextual information about the selected companies is presented in Table 2, showing that most of the companies were younger than 3 years and are mostly in the product-market fit and in scaling phases (see the categorization by Wallin et al., 2015) with turn-overs ranging between zero and $4 \mathrm{M} €$. With few exceptions, most interviewed entrepreneurs were men over 30 years-old with relatively long prior careers in technology, innovation, or entrepreneurship.

The second round of data collection was conducted by accessing publicly available documents and social media data to study what the startups had written about their growth ambitions. The aim of the document analysis was to obtain more detailed data and to triangulate interview data. Finally, the combined interview and document data were analyzed by researchers using content-coding and theme-based categorization. 


\section{Entrepreneurial Growth Ambitions: The Case of Finnish Technology Startups}

\section{Arto Wallin, Kaisa Still, and Katja Henttonen}

Table 2. Contextual information about the 21 Finnish startups in this study

\begin{tabular}{|c|c|c|}
\hline Dimensions & Categories & $\begin{array}{l}\text { Number of } \\
\text { Companies }\end{array}$ \\
\hline \multirow{6}{*}{$\begin{array}{l}\text { Year } \\
\text { Founded }\end{array}$} & 2010 or before & 5 \\
\hline & 2011 & 1 \\
\hline & 2012 & 4 \\
\hline & 2013 & 5 \\
\hline & 2014 & 4 \\
\hline & 2015 & 2 \\
\hline \multirow[t]{4}{*}{ Phase } & Ideation & 2 \\
\hline & Problem-solution fit & 2 \\
\hline & Product-market fit & 10 \\
\hline & Scaling & 7 \\
\hline \multirow{5}{*}{$\begin{array}{l}\text { Turnover } \\
\text { (2015) }\end{array}$} & none & 6 \\
\hline & $<100 \mathrm{k} €$ & 4 \\
\hline & $100-500 \mathrm{k} €$ & 4 \\
\hline & $500 \mathrm{k} €-1 \mathrm{M} €$ & 1 \\
\hline & $>1 \mathrm{M} €$ & 3 \\
\hline \multirow{5}{*}{$\begin{array}{l}\text { Startup } \\
\text { Origin }\end{array}$} & Industrial spin-off & 2 \\
\hline & University spin-off & 3 \\
\hline & $\begin{array}{l}\text { From-scratch, serial } \\
\text { entrepreneurs }\end{array}$ & 5 \\
\hline & $\begin{array}{l}\text { From-scratch, experienced } \\
\text { professionals }\end{array}$ & 9 \\
\hline & $\begin{array}{l}\text { From-scratch, fresh } \\
\text { graduates }\end{array}$ & 2 \\
\hline \multirow{2}{*}{$\begin{array}{l}\text { Entrepreneur } \\
\text { Gender }\end{array}$} & Male & 19 \\
\hline & Female & 2 \\
\hline \multirow{3}{*}{$\begin{array}{l}\text { Entrepreneur } \\
\text { Age }\end{array}$} & $<30$ & 2 \\
\hline & $30-49$ & 15 \\
\hline & $50+$ & 4 \\
\hline
\end{tabular}

\section{Findings and Discussion}

Our analysis of the data shows that, although all studied companies were present at the same startup investor event, there are clear differences between entrepreneurs' ambition levels regarding growth. Intuitively, all companies should be aiming for high growth if they are about to attract private investments. However, surprisingly few companies use language that implies extremely high growth ambitions, and on the other hand, quite a few companies expressed only low or moderate growth expectations (see Table 3 for examples).

\section{How do Finnish startup entrepreneurs express their growth ambitions?}

Table 3 also indicates substantial variation among startup entrepreneurs in their interpretations of growth for their ventures. Expanding international scale $(7 \mathrm{com}-$ panies), referring to geographical coverage of sales, was interpreted by seven startups to be a key indicator for the growth of their company. Increase in market share (6) and turnover (6) were both indicated to be main growth targets for several startups. Growth measured by number of users (4) or customers (1) represented successful growth for five interviewed startups. In addition to these, increase in sales revenue (2) and increased brand recognition (2) were identified as key growth targets. Contradictory to previous research, the number of employees was considered to be a key measure for growth for only two startups. Instead, many startups emphasize that they want to keep their organization small and lean in terms of employees. Finally, one company (the only startup that focused purely on games) regarded the number of downloads as the key measure of growth.

Why do ambition levels differ?

Mostly from the document analysis, we identified numerous potential reasons for the variance in growth ambition levels, from which we will highlight four main categories:

\section{Institutional and market environment}

2. Scalability of business model

3. Founder background and personal characteristics

4. Perception of expectations 


\section{Entrepreneurial Growth Ambitions: The Case of Finnish Technology Startups}

\section{Arto Wallin, Kaisa Still, and Katja Henttonen}

Table 3. Growth ambition levels of the 21 companies in this study

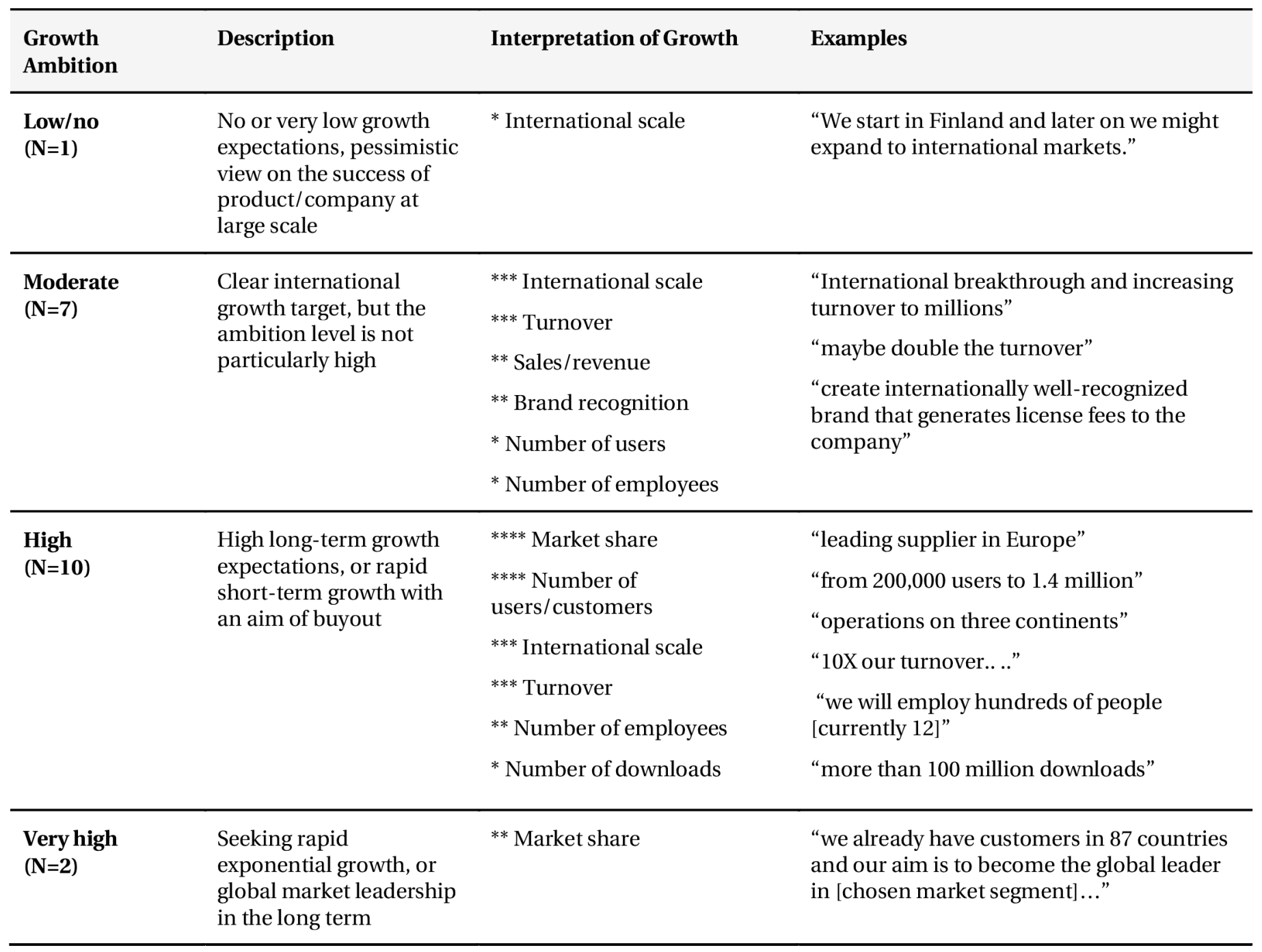

First, the institutional and market contexts that are identified as important in recognition of entrepreneurial opportunity (e.g., Wood \& McKinley 2010) are also important factors in entrepreneurial growth ambitions. The target markets differ among the studied startups, for example, in terms of size, geographical focus, phase, and network effects. Moreover, some markets are highly institutionalized, which constrains the growth of new ventures (e.g., due to laws and regulations). On the one extreme, there are markets of online networking platforms, mobile applications, and games, which have strong network effects. For example, in the mobile game markets, the potential growth can be exponential and extremely rapid: through established channels startups can reach millions of customers on the very same day that a product is launched. Moreover, there are widely known entrepreneurial success stories from Finland in game markets (e.g., Rovio and Supercell), which increases the legitimacy of the game industry and clearly shows the potential for exponential growth and businesses worth of billions of euros. An entrepreneur's perception of the market potential and barriers are therefore partly defined by success stories from the specific market, but also by the success of other players in a comparative market (e.g., aiming to become the Uber of market X).

Second, some companies made business model design choices (Osterwalder \& Pigneur, 2010; Teece, 2010) that notably influenced the scalability of their business. For example, the business was either highly labour intensive (e.g., consulting) or the distribution, sales, or mar- 


\section{Entrepreneurial Growth Ambitions: The Case of Finnish Technology Startups}

Arto Wallin, Kaisa Still, and Katja Henttonen

keting were very labour intensive (e.g., selling to local governments). As a result, entrepreneurs described their business as regionally focused and targeted for city-by-city or country-by-country growth (e.g., "next we will focus on establishing footholds in Sweden and China"). In these cases, entrepreneurs had often realized the limitations of their business model. Accordingly, their growth expectations were mostly moderate and, although they aimed to be international players, the ideal scale of the business was somewhat limited. Given that the impression given by these startups was that they were satisfied with creating profitable businesses in smaller geographical areas, the question remains whether the lack of growth ambition drives a certain type of entrepreneurs to build their business on non-scalable business model?

Third, our data confirm previous research (e.g., Mitchell et al., 2008) showing that growth ambitions strongly depend on the entrepreneurs' personal characteristics and previous experiences. Our data provides three initial insights in this area. For one thing, those entrepreneurs who have previous international experience or a strong entrepreneurial mind-set seem to be inclined to seek faster international growth. For another, those startup founders that are "forced" to become entrepreneurs due to (threat of) unemployment, also referred as necessity entrepreneurship (Block \& Koellinger, 2009) seem to have more modest growth expectations as compared to "opportunity entrepreneurs" that have started businesses not because of fear of unemployment, but because of a tempting business opportunity that they have identified. Lastly, startup founders' understanding of the institutional constraints in the targeted organizational field may explain their growth ambitions, especially in the early stages of entrepreneurship. Initially, it seems that those early-stage entrepreneurs who do not deeply understand institutional arrangements in the field may have more positive growth expectations than those who are more familiar with the specific barriers and constraints related to creating business in that particular field.

Resulting from varying personal characteristics and experiences, our data shows goal incongruence (Vancouver \& Schmitt, 2006) between founders, implying that, in a new venture, some of the co-founders may have significantly different growth expectations than other co-founders, which may also differ from the startups' "official" goals. Our study hints that differing opinions between entrepreneurial founders within a single company seem to be largely based on the personal characteristics, risk-aversive behaviour, and perception of barriers to growth. For example, in one of our cases, one founder said "[in five years] our goal is to have product in the market, but this is my personal perspective, and our CEO has a more optimistic view".

Finally, growth ambitions seem to be refined by the entrepreneurs' perception of the expectations and actions of external stakeholders who either directly or indirectly provide support in commercialization and scale-up of the business. In some cases, a prerequisite for external funding was to steer business to new high-growth markets, thereby external stakeholders were aiming to increase the growth ambition level. However, if the external steering was done forcefully, our impression was that it did not have significant impact on the real growth ambitions of the entrepreneurs. In some other cases, external stakeholders did not directly force the entrepreneur, but the entrepreneurs nonetheless experienced normative pressure that impacted their expression of growth ambition. For example, from the funding perspective, entrepreneurs even joked that you need to have at least three slide decks with different growth projections: (pessimistic/realistic) steady growth projections for banks, middle-of-the-road estimations for the public funding authorities, and overly positive for business angels and venture capital organizations.

Our data implies that the observed behaviour is related to variance in institutional logic and expectations of different types of investors. One the one hand, regulative and normative institutional forces limit risk taking of traditional banks in favour of steady growth instead of gambling for big returns. On the other hand, private investors' portfolio investment strategies are based on high risk and high returns, and therefore they are not usually interested in investment opportunities with low or moderate long-term growth estimates (Feeney et al., 1999). Our findings suggest that entrepreneurs who participate in the activities of a startup ecosystem learn about these institutionalized rules and templates that constrain investment decision making, which leads them to emphasize different aspects of their growth estimates when meeting different investors and funding organizations. Thereby, public funding and private external funding can have substantial impact on the growth strategy of startups.

Startup incubators and accelerator programs are another potential source that may increase an entrepreneur's growth ambitions. First, they usually need to show some level of growth orientation to be accepted into these programs. Second, discussions and potential 


\section{Entrepreneurial Growth Ambitions: The Case of Finnish Technology Startups}

Arto Wallin, Kaisa Still, and Katja Henttonen

co-residence with other growth-oriented startup entrepreneurs, and guidance and inspirational talks from successful entrepreneurs may be an inspiration for higher-growth ambitions. Our interviews and document analysis also provide hints that press and media attention may increase the expressed growth ambitions of startups. In general, extreme cases receive the most media attention, and thereby it may be good strategy for an entrepreneur to emphasize ambitious goals when looking for optimal media visibility.

\section{Theoretical implications}

The numerous studies on entrepreneurial growth ambition form an extensive body of knowledge. This stream of research has been mainly focusing on the objective measurement of the level of growth ambition, where the measure has usually been the number of people employed by the company (e.g., Hermans et al., 2015). Our research departs from the mainstream on two points. First, we view the phenomenon from the constructivist perspective (see e.g., Bouchikhi, 1993) and claim that growth ambition should not be seen as single number; rather, it is a more complex socially constructed phenomenon that emerges from complex interactions between entrepreneurs, their previous experiences and expectations, and other actors and institutional contexts (formal rules, norms, and cultural-cognitive beliefs). Entrepreneurs continually construct their entrepreneurial goals and visions through interactions within their social groups, and when they are exposed to new people, their ambitions may change. They also continuously learn about appropriate and acceptable ways of expressing growth ambitions in different contexts, regardless of their true intentions. Thereby, an entrepreneur may present to potential investors that they want to build a hyperscalable business that will become "the next Google", but at the same time they may be secretly applying for a more secure job at a large corporation. The level of growth ambition also depends on the perspective of observers as two different people evaluating growth may have different normative views and cultural-cognitive scripts that guide their evaluation. All this leads to the conclusion that there can be several coexisting views on the level of growth ambition, and one view does not need to be judged as true or false.

Second, our study highlights that the concept of growth is interpreted differently among entrepreneurs. For many Finnish startup entrepreneurs, growth is still about expanding the business to international markets, which can be considered as a quite conservative view on growth in a small nation that has always relied heavily on foreign trade. Even though all startups are focus- ing on digital product and services, in a business-tobusiness or business-to-government context, there is in many cases a lot of work that requires physical presence and therefore the perspective is: "how do we expand to the next geographical area". For entrepreneurs whose business relies on global digital delivery channels, the growth ambition can be very different. For them, country-by-country growth is not necessarily relevant, although country-specific customization might still be an issue (e.g., due to different languages). However, they are more focused on how many users or customers they have, and how they can grow the user/customer base while keeping their operational efficiency at a high level. In contrast to previous research, our findings clearly indicate that growth in terms of number of employees is not necessarily the main target for technology startups. Instead, many of the startups we studied aim to build their businesses such that the scalability of their businesses are not strongly linked to the number of employees, and the possibility of becoming a large hierarchical organization is seen as a threat to long-term success.

\section{Practical and policy implications}

This work supports the national and local policy makers responsible for new venture funding and decision makers of startup ecosystems (e.g., managers of accelerator programs) who design and offer supportive actions for startup entrepreneurs. Our study helps these actors to better understand the differences between startups that operate in different institutional contexts, that perceive different pressure and constraints, and that have different levels of ambition and goals for their business. Based on our study, it is neither realistic nor beneficial to expect the same level of growth ambition from startups that aim for different types of markets by executing business models that are very different from the scalability perspective. Moreover, the entrepreneurs' previous and current social contexts can be seen as social constructs that define informal rules on how growth ambitions are expected to be expressed. Thereby, understanding the diversity of startups helps to tailor specific support to the different types of startups or helps to recognize which startups would benefit most from the provided support.

The study also has practical implications for entrepreneurs. First, individuals considering jumping onto the path of entrepreneurial innovation can gain a better understanding of the varying perspectives and expectations within a startup ecosystem regarding growth. Second, startup entrepreneurs who already are on the entrepreneurial innovation path can learn from the ex- 


\title{
Entrepreneurial Growth Ambitions: The Case of Finnish Technology Startups
}

\author{
Arto Wallin, Kaisa Still, and Katja Henttonen
}

pressed growth ambitions of other entrepreneurs and benchmark their growth ambitions relative to other entrepreneurs.

\section{Limitations}

One of the main challenges in conducting research that aims to reveal the delicate issue of ambition level, which might for example impact greatly on a startup's funding, is how to ensure that the data will be reliable. We acknowledge that entrepreneurs learn how they are expected to express their growth ambitions in different social contexts and in some cases it may be difficult for a researcher to create sufficient trust within a short timeframe to overcome this learned behaviour. Even though a startup investment event is assumed to be a context where entrepreneurs are expected to overemphasize their growth ambitions, only very few startups showed very high growth ambitions. This finding may indicate that a researcher is seen as a more impartial actor even though the setting for the interview is an investor event. Regardless of the truthfulness of their answers, due to the socio-constructivist stance, our aim is not to find a single objective truth about the level of growth ambition, but to create better understanding about the phenomenon by exploring different views and explanations that are embedded in the different social contexts experienced by entrepreneurs.

\section{Conclusion}

During the last few decades, there has been significant interest in entrepreneurship research that examines how individual-level factors correlate with entrepreneurship and commercialization behaviours (e.g., Nelson, 2014). This article focuses on entrepreneurial growth ambitions and takes a socio-constructivist view on answering the question: what kind of growth do technology entrepreneurs aim for and why there are differences in growth ambition levels? Our data from the context of the Finnish startup ecosystem provide empirical findings that the concept of growth differs between startups. For some companies, growth is geographical expansion, for others it is more about num- ber of users or customers, regardless of their origin. For most of the startup companies we studied, growth in terms of the number of employees is not the goal, which may be somewhat contradictory to the goals of the policy makers that aim to increase employment in general.

We contribute to the theoretical discussion by suggesting that growth ambitions should be seen as a more complex socially constructed concept than just an easily observable value defining the level of ambition. In our cases, growth ambitions were influenced at least by the perception of market potential and the social context they are embedded in, the scalability of the business model, personal characteristics and background of entrepreneurs, and their perceptions of the barriers and constraints of the field. We claim that different types of startup companies have different needs and therefore the support provided to those startups should be different. It is also worth considering whether all kinds of startups need equal support.

\section{Acknowledgements}

This research was conducted as a part of an international RDI project (Accelerate/ITEA3), which aims to develop tools to accelerate the startup innovation process. Our research is a follow-up of previous research within that project that concentrated on the research question of the key concerns of growth-seeking entrepreneurs in Finland (Wallin et al., 2015). The authors would like to express their gratitude to the Finnish Funding Agency for Innovation (Tekes), the Technical Research Centre of Finland (VTT), and other parties involved in the Accelerate project for their financial support.

An earlier version of this article was presented at the 2016 ISPIM Innovation Conference in Porto, Portugal, June 19-22. ISPIM (ispim.org) - the International Society for Professional Innovation Management - is a network of researchers, industrialists, consultants, and public bodies who share an interest in innovation management. 


\section{Entrepreneurial Growth Ambitions: The Case of Finnish Technology Startups}

\section{Arto Wallin, Kaisa Still, and Katja Henttonen}

\section{About the Authors}

Arto Wallin is a Senior Scientist and Project Manager at VTT (Technical Research Centre of Finland) in the Business, Innovation and Foresight research area. For last four years, his work has focused on business consulting, and he has helped numerous ehealth startups and SMEs in the commercialization of their innovations. His recent scientific interest has been on the startup innovation process, service innovation and management, and institutional change, particularly in the field of healthcare.

Kaisa Still is a Senior Scientist at VTT (Technical Research Centre of Finland) and Visiting Scholar at mediaX at Stanford University. Supporting collaboration and innovation with technology continues to be at the core of her career. Her current work concentrates on platforms and innovation ecosystems, accelerating innovation activities, and digital opportunities. Combined with the policy perspective, her work extends to private and public organizations, in regional and global contexts.

Katja Henttonen is a specialist at the VTT (Technical Research Centre of Finland) in a team studying digital transformations in organizations and society. She holds an MSc degree in ICT and socio-economic development from the University of Manchester and is working towards a $\mathrm{PhD}$ at the University of Jyväskylä, Finland. Since joining VTT in 2006, she has worked in several research projects on technology, innovation, and entrepreneurship. Prior to that, she worked for almost ten years in the software business, both in professional and consulting roles.

\section{References}

Andrade, A. D. 2009. Interpretive Research Aiming at Theory Building Adopting and Adapting the Case Study Design. The Qualitative Report, 14(1): 42-60.

Autio, E., Kenney, M., Mustar, P., Siegel, D., \& Wright, M. 2014. Entrepreneurial Innovation: The Importance of Context. Research Policy, 43(7): 1097-1108.

http://dx.doi.org/10.1016/j.respol.2014.01.015

Autio, E., \& Rannikko, H. 2016. Retaining Winners: Can Policy Boost High-Growth Entrepreneurship? Research Policy, 45(1): 42-55. http://dx.doi.org/10.1016/j.respol.2015.06.002

Bailetti, T. 2012a. Technology Entrepreneurship: Overview, Definition, and Distinctive Aspects. Technology Innovation Management Review, 2(2): 5-12. http://timreview.ca/article/520

Bailetti, T. 2012b. What Technology Startups Must Get Right to Globalize Early and Rapidly. Technology Innovation Management Review, 2(10): 5-16.

http://timreview.ca/article/614

Block, J., \& Koellinger, P. 2009. I Can't Get No Satisfaction - Necessity Entrepreneurship and Procedural Utility. Kyklos, 62(2): 191-209. http://dx.doi.org/10.1111/j.1467-6435.2009.00431.x

Bosworth, M. 2014. The Upside to Being Let Go by Nokia. BBC Magazine, January 31, 2014. Accessed October 1, 2016:

http://www.bbc.com/news/magazine-25965140

Bouchikhi, H. 1993. A Constructivist Framework for Understanding Entrepreneurship Performance. Organization Studies, 14(4): 549-570.

http://dx.doi.org/10.1177/017084069301400405

Carbone, P. 2009. Accelerating Successful Technical Entrepreneurship. Open Source Business Resource, August: 19-24. http://timreview.ca/article/278

Carbonell, P., Rodriguez-Escudero, A., \& Pujari, D. 2009. Customer Involvement in New Service Development - An Examination of Antecedents and Outcomes. Journal of Product Innovation Management, 26: 536-550. http://dx.doi.org/10.1111/j.1540-5885.2009.00679.x

Cassar, G. 2006. Entrepreneur Opportunity Costs and Intended Venture Growth. Journal of Business Venturing, 21(5): 610-632. http://dx.doi.org/10.1016/j.jbusvent.2005.02.011

Cassar, G. 2007. Money, Money, Money? A Longitudinal Investigation of Entrepreneur Career Reasons, Growth Preferences and Achieved Growth. Entrepreneurship \& Regional Development, 19(1): 89-107. http://dx.doi.org/10.1080/08985620601002246

Chetty, S. 1996. The Case Study Method for Research in Small- and Medium-Sized Firms. International Small Business Journal, 15(1): 73-85. http://dx.doi.org/10.1177/0266242696151005

Cliff, J. E. 1998. Does One Size Fit All? Exploring the Relationship between Attitudes towards Growth, Gender, and Business Size. Journal of Business Venturing, 13(6): 523-542. http://dx.doi.org/10.1016/S0883-9026(97)00071-2 


\section{Entrepreneurial Growth Ambitions: The Case of Finnish Technology Startups}

\section{Arto Wallin, Kaisa Still, and Katja Henttonen}

Davidsson, P. 1989. Entrepreneurship - And After? A Study of Growth Willingness in Small Firms. Journal of Business Venturing, 4(3): 211-226.

http://dx.doi.org/10.1016/0883-9026(89)90022-0

Feeney, L., Haines, G. H., \& Riding, A. L. 1999. Private Investors' Investment Criteria: Insights from Qualitative Data. Venture Capital, 1(2): 121-145.

http://dx.doi.org/10.1080/136910699295938

Freeman, J., \& Engel, J. S. 2007. Models of Innovation: Startups and Mature Corporations. California Management Review, 50(1): 93-119.

http://dx.doi.org/10.2307/41166418

Ghauri, P. 2004. Designing and Conducting Case Studies in International Business Research. In R. Piekkari \& C. Welch (Eds.), Handbook of Qualitative Research Methods for International Business: 109-124. Cheltenham, UK: Edward Elgar Publishing. http://dx.doi.org/10.4337/9781781954331.00019

Giones, F., \& Miralles, F. 2015. Do Actions Matter More than Resources? A Signalling Theory Perspective on the Technology Entrepreneurship Process. Technology Innovation Management Review, 5(3): 39-45.

http://timreview.ca/article/880

Giones, F., Zhou, Z., Miralles, F., \& Katzy, B. 2013. From Ideas to Opportunities: Exploring the Construction of Technology-Based Entrepreneurial Opportunities. Technology Innovation Management Review, 3(6): 13-20. http://timreview.ca/article/692

Gundry, L. K., \& Welsch, H. P. 2001. The Ambitious Entrepreneur: High Growth Strategies of Women-Owned Enterprises. Journal of Business Venturing, 16(5): 453-470.

http://dx.doi.org/10.1016/S0883-9026(99)00059-2

Hermans, J. H., Vanderstraeten, J. V, Van Witteloostuijn, A., Dejardin, M., Ramdani, D., \& Stam, E. 2015. Ambitious Entrepreneurship: A Review of Growth Aspirations, Intentions, and Expectations. In J. Katz \& A. C. Corbett (Eds.), Advances in Entrepreneurship, Firm Emergence and Growth: 127-160. Bingley, UK: Emerald Group Publishing Ltd.

http://dx.doi.org/10.1108/S1074-754020150000017011

Knight, G. 2015. Born Global Firms: Evolution of a Contemporary Phenomenon. Entrepreneurship in International Marketing, 25: $3-19$.

http://dx.doi.org/10.1108/S1474-797920140000025001

Knight, G., \& Cavusgil, S. T. 1996. The Born Global Firm: A Challenge to Traditional Internationalization Theory. In S. T. Cavusgil \& T. Madsen (Eds.), Advances in International Marketing: 11-26. Greenwich, CT: JAI Press.

Kolvereid, L. 1992. Growth Aspirations among Norwegian Entrepreneurs. Journal of Business Venturing, 7(3): 209-222.

http://dx.doi.org/10.1016/0883-9026(92)90027-O

Lane, E. 2016. Nokia: Life after the Fall of a Mobile Phone Giant. $B B C$ News, March 18, 2016. Accessed October 1, 2016: http://www.bbc.com/news/business-35807556

Lee, J. H., \& Venkataraman, S. 2006. Aspirations, Market Offerings, and the Pursuit of Entrepreneurial Opportunities. Journal of Business Venturing, 21(1): 107-123. http://dx.doi.org/10.1016/j.jbusvent.2005.01.002
Mason, C., \& Brown, R. 2013. Creating Good Public Policy to Support High-Growth Firms. Small Business Economics, 40(2): 211-225. http://dx.doi.org/10.1007/s11187-011-9369-9

Mills, M., van de Bunt, G., \& de Bruijn, J. 2006. Comparative Research: Persistent Problems and Promising Solutions. International Sociology, 21(5): 619-631. http://dx.doi.org/10.1177/0268580906067833

Minniti, M., Bygrave, W., \& Autio, E. 2005. Global Entrepreneurship Monitor: 2005 Executive Report. London: Global Entrepreneurship Research Association. http://gemconsortium.org/report/47104

Mitchell, R., Mitchell, R., \& Smith, B. 2008. Inside Opportunity Formation: Enterprise Failure, Cognition, and the Creation of Opportunities. Strategic Entrepreneurship Journal, 2(3): 225-242. http://dx.doi.org/10.1002/sej.51

Nelson, A. J. 2014. From the Ivory Tower to the Startup Garage: Organizational Context and Commercialization Processes. Research Policy, 43(7): 1144-1156. http://dx.doi.org/10.1016/j.respol.2014.04.011

Osterwalder, A., \& Pigneur, Y. 2010. Business Model Generation. Hoboken, NJ: John Wiley and Sons.

Schumpeter, J. A. 1934. The Theory of Economic Development. Cambridge, MA: Harvard University Press.

Schwab, K., \& Sala-i-Martin, X. 2014. The Global Competitiveness Report 2014-2015. Geneva: World Economic Forum. http://reports.weforum.org/global-competitiveness-report-20142015/

Sipola, S. 2015. Understanding Growth and Non-Growth in Entrepreneurial Economies. Analysis of Startup Industries and Experimental Winner Generation in Finland, Israel and Silicon Valley. Doctoral Dissertation. University of Oulu, Finland. http://urn.fi/urn:isbn:9789526208138

Sipola, S., Puhakka, V., \& Mainela, T. 2016. A Start-Up Ecosystem as a Structure and Context for High Growth. In T. M. Devinney, G. Markman, T. Pedersen, \& L. Tihanyi (Eds.), Global Entrepreneurship: Past, Present \& Future (Advances in International Management, Volume 29): 179-202. Bingley, UK: Emerald Group Publishing Limited.

Takahashi, D. 2016. With Just 3 Games, Supercell made $\$ 924 \mathrm{M}$ in Profits on \$2.3B in Revenue in 2015. VentureBeat, March 9, 2016. Accessed October 1, 2016: http://venturebeat.com/2016/03/09/with-just-3-games-supercellmade-924m-in-profits-on-2-3b-in-revenue-in-2015/

Tanev, S. 2012. Global from the Start: The Characteristics of BornGlobal Firms in the Technology Sector. Technology Innovation Management Review, 2(3): 5-8. http://timreview.ca/article/532

Teece, D. J. 2010. Business Models, Business Strategy and Innovation. Long Range Planning, 43(2-3): 172-194. http://dx.doi.org/10.1016/j.lrp.2009.07.003

Tominc, P., \& Rebernik, M. 2007. Growth Aspirations and Cultural Support for Entrepreneurship: A Comparison of Post-Socialist Countries. Small Business Economics, 28(2-3): 239-255. http://dx.doi.org/10.1007/s11187-006-9018-x 


\section{Entrepreneurial Growth Ambitions: The Case of Finnish Technology Startups} Arto Wallin, Kaisa Still, and Katja Henttonen

Wallin, A., Still, K., \& Komi, M. 2015. Start-up Entrepreneurs' Key Concerns on Path of Entrepreneurial Innovation. Proceedings of the XXIV ISPIM Conference, June 14-17, 2016. Budapest, Hungary.

Walsham, G. 1995. Interpretive Case Studies in IS Research: Nature and Method. European Journal of Information Systems, 4(2): $74-81$.

http://dx.doi.org/10.1057/ejis.1995.9

Vancouver, J. B., \& Schmitt, N. W. 2006. An Exploratory Examination of Person-Organization Fit: Organizational Goal Congruence. Personnel Psychology, 44(2): 333-352. http://dx.doi.org/10.1111/j.1744-6570.1991.tb00962.x

Verheul, I., \& van Mil, L. 2011. What Determines the Growth Ambition of Dutch Early-Stage Entrepreneurs? International Journal of Entrepreneurial Venturing, 3(2).

http://dx.doi.org/10.1504/IJEV.2011.039340

Wiklund, J., Davidsson, P., \& Delmar, F. 2003. What Do They Think and Feel about Growth? An Expectancy-Value Approach to Small Business Managers' Attitudes Toward Growth. Entrepreneurship Theory and Practice, 27(3): 247-270.

http://dx.doi.org/10.1111/1540-8520.t01-1-00003

Wood, M. S., \& McKinley, W. 2010. The Production of Entrepreneurial Opportunity: A Constructivist Perspective. Strategic Entrepreneurship Journal, 4(1): 66-84.

http://dx.doi.org/10.1002/sej.83

Citation: Wallin, A., Still, K., \& Henttonen, K. 2016.

Entrepreneurial Growth Ambitions: The Case of Finnish

Technology Startups. Technology Innovation

Management Review, 6(10): 5-16.

http://timreview.ca/article/1023

Keywords: startups, growth ambitions, entrepreneurial innovation 